\title{
Caderno de poesias II
}

\author{
Irene Severina Rezende ${ }^{1}$
}

\author{
METRÔ \\ da cidade escolho os trens \\ pelo eco e \\ pelo brilho dos olhos \\ dos de dentro, \\ que com instantes de sagrada solidão \\ desenrolam novelos \\ de infinitos... \\ Com sonhos desmedidos \\ do existir a qualquer medida \\ pobremente só, vêm \\ do morro, \\ do Cristo, \\ do mar \\ na surdez de passos... \\ à noite \\ estendo-me a respirar
}

fundas vontades de supetão 
Espanto o desleixo e o mofo dos pensamentos

Ao dia optei pela indiferença

peguei do bastidor e não adulei o gato

\section{FIDELIDADE}

Que venha o poente e traga você em suas asas

na quinta-feira sou ninguém

ecoarei pedaços de espera temas uníssonos, rolarão de mim: sua amor, que sou peão!,

dos mais apaixonado sou seu rei, seu braço, seu esteio sem alcançar sentido.

Terra de ninguém sem transe

em trajetória de mosca 
nessa urgência de relações imediatas

meu nome,

em fases

que nunca encontrei,

sou cada uma delas,

no fim mudo a letra

-muda a voz-

\section{MEMÓRIA}

abridor de caminhos, cravou na fachada:

$$
\text { 1950, }
$$

dignidade de data antiga, conservada em naftalina

rosto de um tempo, ela me altera:

deslocada do passado,

lhe contemplo: 1950

entre o período e a palavra

o hoje inexiste.

Memória mais malhada

nela o passado respira

à sombra dos coronéis

feito onças

que ancoraram em nossas margens,

projetada no último Maia

homem fazendeiro

constrói pontes

de ignorância

em sua travessia

o carro de bois passa, e 
nos olhos dos bois um povo minguado.

Costuro o tempo presente

1950 não me conforta,

é antepassado confluindo em mim,

a me confirmar

a vida derivada vai longe encantar,

esvaindo dentre todas

as portas do mundo

\section{CANTO}

aquilo que sempre fui:

"Baú feito de itaúba preta,

de flores insignificantes;

Pilão de monjolo

onde não trafega canoa;

sucuri do boiadeiro

que vomita na correnteza;

Pé descalço, roupa branca,

entre trilhas, sofro de ajustes;

Curvada sob o peso da mata

sou fácil de assustar;

Palavras me caem e

espirro cores de Abril; 
Sem ordem,

sou tropa batida,

- Não é tropa, é eleitor”

\section{SEU PERFUME}

minha anágua ainda respira

o mundo do sertão,

bagaços da pindaíba

flutuam pela minha lembrança

sem muita elegância;

uma lua indecisa,

passeia pela serra;

seu amor, ausente

perturba minha lembrança

queima-me,

como prolongamento

procuro pelas horas

encontro gafanhotos mortos

misturo batom ao seu cheiro

que meu aposento inda respira

seu amor, agasalhou

meus gestos

e dilatou-se em explicações,

mas sua camisa xadrez

nunca me atraiu. 


\title{
NO MATO GROSSO
}

\author{
Carro não cabe
}

Cavalo pisa a lama

Comitiva avança

Bois na água.

O grito do peão

atravessa o rio a nado

cantoria galopa e salta

na espora de ferro batido

\author{
A vitória-régia \\ flor de uma parte só \\ parte o sol \\ a duas braças de entrar \\ a noite. \\ Andorinha migrou \\ frio chegou no norte \\ e nas pontas das almas \\ bicho-de-pau é ambiente \\ Curupira, tem não \\ é espetáculo na mente do vaqueiro
}




\title{
DE COR
}

\author{
Olho o horizonte \\ são restos de cores que se descolaram do meu ser \\ hoje sou cinza \\ cedi-lhe minhas cores pra eternizar a beleza
}

a existência aventurei de navegantes,

a remo, colhi cada devaneio

caí em erros e entre nós se abriu lacuna

não aceitei seu amor

no pôr-da-noite.

sem razão aparente

me deixo levar pelo azul

que aponta pra um horizonte

desmaiado de beleza;

Em sabor desagradável,

você -inteiro- turva meu entardecer

como relíquia incrustada pra sempre

em meu olhar,

falso que nem espelho...

mas no pasto

a urutau, mãe da lua,

ainda repica

os lamentos dos bororos 


\author{
ANOS DE \\ Você é da fazenda? \\ paternalista refinado: \\ -não, minha filha, \\ a fazenda é que é minha!
}

a moça da cidade enxergou em razão:

50 anos estudei só os mapas,

dentro, e do sertão;

sobre o mar nunca pisei,

se castelos de serras adornam meu sítio?:

se é no açafrão-da-terra

que espalho minhas lembranças?;

se passei a vida na capoeira

a marchar com os ventos?;

se carreguei sonhos na cabaça e

na sabedoria do mato?;

se meu espírito se entrega ao presente?

e vagueia deserto

e vagueia desperto

e sabe

que o encontro com o mundo

pode ser por episódios neutros.

\title{
SONHOS
}

Caminho das garças

Caminhos de gerações

Pra uma que,

reinarão mil outras

imutáveis 
em novos ritmos

apresentadas ao ar livre,

do luar

Num tempo afora do lugar

repicando cantos miúdos

ainda cobrirão nossos céus

as garças e os sonhos...

Quanto aos cantos de todas

as aves

ouvirás os restos de sopros

expandirem-se

nas orelhas de todo poeta 


\section{PESCARIA NO MATO}

cismei de ver a mãe d'água brotando

no batedor

demorei um tantin;

a nos espiar as sombras e os passos, uma baita duma onça

mudei o anzol entre dois sois

Lameei nos prados meu grão de espera

O texto da roça é sempre demorado

oculta o susto da cilada

À cidade seus demônios e seus artistas

- O amanhecer pro sertão descuidado nas margens, no umbigo da noite,

o entardecer põe barulho de garças nas barrancas do rio, vem somar a agudeza da sereia em hora aberta, é por onde a vida é ou vida...

pensamento se refaz em dois anis: enquanto se pode viver sempre do lado que não se espera, respiro a dança das últimas águas.

1 Mestre e doutoranda em Estudos Comparados de Literaturas de Língua Portuguesa (Faculdade de Filosofia, Letras e Ciências Humanas, Universidade de São Paulo). 